Editorial

\title{
Collaboration and Sustainability: Making Science Useful, Making Useful Science
}

\author{
Edward J. Hackett ${ }^{1,2}$ (1) \\ 1 Office of the Provost MS 134, Brandeis University, Waltham, MA 02453, USA; ehackett@asu.edu \\ 2 School of Human Evolution and Social Change, Arizona State University, Tempe, AZ 85282, USA
}

Received: 4 November 2020; Accepted: 8 November 2020; Published: 11 November 2020

\begin{abstract}
Collaboration is essential to produce the distinctive forms of science and technology—knowledge and know-how-required to meet sustainability challenges. What might be the form of that collaboration? One-shot or transient collaboration is giving way to richer, deeper, continual integration of knowledge, power, and diverse ethics and values (ethos), and these, in turn, confront leaders and analysts with new challenges.
\end{abstract}

Keywords: collaboration; sustainability; interdisciplinarity; development; values

Between the idea
And the reality
Between the conception
And the creation

Falls the shadow

T.S. Eliot, The Wasteland, 1925

People who build networks will tell you that the last mile is the toughest. The backbone and main structure of the network are relatively easy to construct but connecting the structure to individual homes and users is quite difficult. There are many users to attach to the network, of course, so there are many "last miles", and they present builders with a variety of distinct needs and challenges.

Knowledge and know-how travel a last mile, too, as they move from idea to reality, from conception to creation, from the minds and hands of their origins to the people and places where they are put to work. The last mile is the interval "between the idea and the reality", between our best intentions and their realization in the lives of people who reside in a particular place at a particular time. For those who wish to apply knowledge to meet sustainable development goals, for example, the last mile is a perilous path to travel alone: hippos come out of the river to eat tomatoes that were carefully planted and cultivated (Ernesto Sirolli), genetically modified corn stalks prove too short to support bean plants and too tough to feed livestock (a story William Foote Whyte would tell of his experience with farmers in Latin America), and smoke-free indoor cook stoves permit bugs growing in a thatched roof to overwhelm the hut's inhabitants (Jameson Wetmore, personal communication). In the last mile we discover what we wish we knew when we set out.

Meeting such challenges requires collaboration-a process of creation, adjustment, becoming - that recombines the diverse expertise of many disciplines and professions. Experience, trials, and errors taught us the need for collaboration and creative recombination. Unsuccessful attempts to apply scientific knowledge and technological know-how to sustainability challenges were initially blamed on deficiencies in the knowledge or technology itself. The appropriate technology movement of 
the 1960s and 1970s took this perspective, positing that the right technologies-inexpensive, small-scale, labor-intensive, adaptable-are needed to suit human needs in particular contexts [1,2]. Small is beautiful, we thought then, and so we produced small-scale knowledge and know-how, then hoped for the best.

With time we learned that smallness alone was not beautiful enough. To be effective, scientific knowledge and technological know-how needed to appear salient (or relevant), credible, and legitimate to those who would use it [3], addressing problems important to the community using convincing evidence that is consonant with local beliefs and understandings. Much of importance was left unsaid: how to make knowledge salient, credible, and legitimate; whether such qualities are stable over time or need refreshment; and how to reconcile local, tacit, and indigenous forms of knowledge and know-how with imported varieties.

Research in science and technology studies and cognate fields has shown that science and technology (knowledge and know-how) are formed through social processes, acquiring salience, credibility, legitimacy, and other qualities along the way [4-6]. Recognizing this directs attention to the processes of social construction, co-production, and mutual constitution that take place in transdisciplinary collaborations among scientists, engineers, professionals, practitioners, and community members [7-9]. Sustainability scholars are well aware that producing usable knowledge requires collaboration among diverse parties, and that catalyzing, guiding, and sustaining such collaborations are a grand challenge for sustainability scholarship [10,11]. A lone traveler cannot convey knowledge and know-how over the last mile: it takes a team to connect idea and the reality, intention and act.

Figure 1, reproduced from Reid et al. [12], summarizes the decades-long progression of models representing collaboration among scientists and local community members and practitioners in their Africa-based agricultural research. Over the years, these interactions evolved from a null model of no contact at all-scientists produced and published scientific research, leaving others to find and use it-through a mixed model that featured brief exchanges at the beginning or end (or both) of a research project, intended either to motivate researchers by posing a practical problem or to assist practitioners in the application (or transfer or translation) of knowledge into application-to the current best practice of "continual engagement among communities, policy makers, NGOs, and researchers" [12]. However, what is the nature of this engagement? What do the strands represent or convey? What are the places they connect?

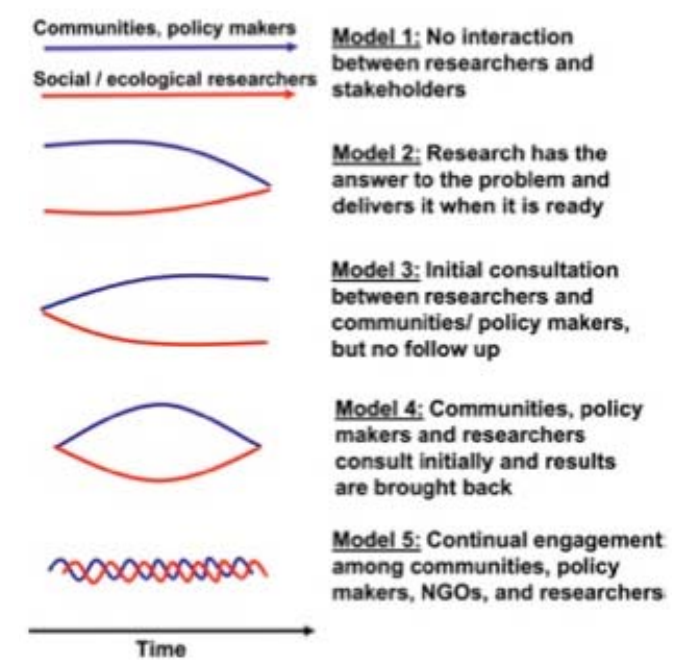

Figure 1. Evolution of our models to link knowledge with action in pastoral systems of East Africa over the last 3 decades [12]. 
The entangled strands represent at least three things that are conveyed or created through collaboration:

Knowledge and know-how understood broadly to include not only formal science and engineering brought by experts into the local setting but also the local, sentient, tacit, and indigenous forms of knowledge present in a place $[13,14]$. These forms of knowledge, sometimes in agreement and other times not, are a dialog unfolding over time. For example, different forms of knowledge may disagree about which plant varieties are best suited for particular soils, landscapes, and climatic conditions, and how much fertilizer and water to apply and when to do so $[15,16]$.

Some of the most consequential knowledge resides within, in places its bearer may not know of or be able to access consciously, and so is taught and learned in implicit and less explicable ways. Farmers, for example, are aware of the subtle differences in soil, moisture, exposure, drainage, and such that influence what should be planted and when. Yet how does one decide when to follow the general rule and when to make exceptions for local conditions? Knowledge of this sort is situated in the special characteristics of places, the experiences of a community, and the lessons learned through tradition.

Power in various forms-authority, influence, and force-constitutes a second strand of the cable, because every transfer of knowledge or know-how unsettles the existing distribution of power. We learn this memorably from fiction: In A Connecticut Yankee in King Arthur's Court [17] Hank Morgan, the title character, uses his technical knowledge and engineering skill (imported from the 19th century United States) to do things that locals experience as powerful magic, displacing Merlin the magician as King Arthur's advisor and confidant. Today, agricultural innovations shift power between women and men, new fuels disadvantage vendors of wood for cooking, food aid unsettles the local food economy, cell phones put middlemen out of business, and improved medical services threaten the livelihood of traditional healers. If, as Arthur C. Clarke [18] claims, "Any sufficiently advanced technology is indistinguishable from magic", then there may be no compelling reason to place greater faith in the imported ideas of formal science, engineering, or medicine than in traditional ideas of local origin: the effects of either may appear to be magical, after all, and beyond further human explanation.

Ethos, or the ethics, values, and moral principles that help members of a community to determine the right thing to do in particular circumstances, constitute the third major strand of the interaction. Cultures differ in what is proper conduct, a valued purpose, and a fair means of accomplishing that purpose, and cultures clash over disagreements about such standards [19].

The interplay of knowledge, power, and ethos represented in the figure describes the complex social and cultural transactions of collaboration. The continuity, amplitude, and periodicity of the entwined lines will not be as smooth or stable as they appear. Real interactions will break down at times or have uneven frequencies and amplitudes in the course of sharing knowledge, exercising power, or reconciling ethical differences. Impasses, tectonic shifts, and occasional eruptions are more likely than an even weave of transfer, acceptance, and application. The characteristics, causes, and consequences of such episodes-hot spots and hot moments-are strategic sites for research and intervention [20].

Beyond what each line conveys, the entwined lines imply that the qualities of each engage others in meaningful ways. Differences may arise when varied forms of knowledge or know-how collide, and for such critical exchanges to be effective, participants must understand one another well enough and feel empowered enough to question or criticize. However, differences in the ability to understand and use the formalism and abstraction of science and technology, deference to expertise of various sorts, cultural values (about accepting gifts and reserving criticism, for example) may complicate working together. To restore balance, collaborators must be able to probe, doubt, test, or criticize, to question or challenge proposed explanations and courses of action.

Multiplex and entwined lines are poor symbols for representing the diverse epistemic and cultural dynamics of collaboration: for greater accuracy we need breaks to mark interruptions, thicknesses to represent surfeits, bumps to symbolize blockages, warm colors to represent heated interactions, and something like anti-lines to represent error, failure, betrayal, and the transitory sparks of annoyance 
that arise in even the best collaborations. If we imagine that the lines in Figure 1 connect two different places - at once joining the places and yet demarcating them-we are led to ask how identity is formed and maintained and how boundaries are mapped and [21,22]. Boundary organizations promote distinctive forms of collaboration and knowledge [23-25]. Drawing upon decades of collaborative experience with African farmers, Reid and colleagues [12] observe that, of all the forms of knowledge, the most sophisticated level [of knowledge created or provided], and the most rarely implemented, was "hybrid knowledge creation", wherein the facilitator, community members, and researchers created hybrid information [knowledge and know-how] together (policy makers were sometimes consulted in this process). From a community and policy perspective, this hybrid knowledge brought the reliability of scientific information into the community and policy decision-making processes. From a scientific perspective, this hybrid knowledge ensured relevance of the science and allowed a wider and deeper interpretation of the information collected [12].

Hybrid knowledge is created through a collaboration that spans borders but is otherwise unspecified, except to say that it is a sophisticated, rare, and valuable form of knowledge that benefits each collaborator in its own way. What are the design principles for building collaborative places that produce integrative, synthetic, or hybrid knowledge and know-how? What are the impediments and challenges encountered during collaboration?

The papers collected in this special issue explore various facets of collaboration at different scales and in different modalities. For example, we learn that mediating structures, facilitating organizations, and artefacts promote transdisciplinary collaboration (Dragomir et al.; Moreno-Serna et al.; Molinengo and Stasiak). However, there are no sure things: technocratic approaches prevailed when collaboration was constrained by institutional factors, governance, technology, or culture (Jackson et al.) and a co-design project improved smallholder farmers' understanding and use of smart phones but did not increase their power or trust (Agyekumhene et al.). A Delphic panel identified eight factors (out of 58) that aided collaboration, including broad representation of stakeholders, a common problem, shared vision, and legitimate, adaptable ends (Pugel et al.), and a fortuitous natural experiment underscored the disruptive influence of stakeholder exclusion (Curseu et al.). Conventional collaboration, desirable and difficult as it may be to achieve, is not certain to change organizational practice (Fobbe) and may not be equal to the sustainability challenges of the day. Innovation is required and may arrive in the form of "co-creation" (Herberg et al.) or multiplex learning across disciplines, cultures, and contexts to negotiate diverse epistemic frames and normative commitments (Ely et al.). Reaching further, Casper Bruun Jensen et al. suggest that a sophisticated conjunction of epistemologies, methods, and practices is required to create conditions conducive to productive transdisciplinary collaboration. Accepting the challenge, Edgar Cardenas and Sandra Rodegher examine how art-science teams reason together, validate one another's work, and produce robust approaches to complex socio-environmental problems. In a perceptive and forward-looking analysis, Julie Thompson Klein positions the concept of interdisciplinarity among a handful of cognate terms (integration, confluence, interdependence, interaction, and balance), clarifying concepts and outlining an agenda for research. Finally, three papers look outward toward the ends of collaboration to reduce greenhouse gas emissions (Sun et al.), to increase inter-institutional, international, or cross-sector publication in the sustainable mining literature, or to support international, inter-institutional, or cross-sectoral collaboration (Bemke-Świtilnik et al.). Taken as a whole, these papers explore how varied forms of collaboration make knowledge and know-how useful for engaging the wicked problems of sustainability.

The diverse knowledge and know-how required to address sustainability challenges must be brought, not sent, embodied in a varied collection of experts. In the last mile they meet and collaborate with local experts to craft and fit onsite sustainability solutions-remedies might more accurately express their ephemeral nature-that meet local needs and incorporate local knowledge and know-how, beliefs and values.

Funding: This research received no external funding. 
Acknowledgments: I am deeply grateful to the Institute for Advanced Sustainability Studies in Potsdam, Germany, for providing the intellectual context, interactions, and challenges that inspired this paper. Special thanks to Professor Klaus Töpfer, Falk Schmidt, Jes Weigelt, Julia Schmale, Moritz Remig, Jörg LeBlanc, Manuel Rivera, and Professor Hallie Eakin for various opportunities to discuss and develop the ideas presented in this paper. A version of this paper was presented as opening remarks for "Between Two Worlds: Social and Spatial Sciences on the Way to a New Understanding of Knowledge Transfer", Wissenschaftszentrum Berlin für Sozialforschung.

Conflicts of Interest: The author declares no conflict of interest.

\section{References}

1. Schumacher, E.F. Small Is Beautiful; Blond and Briggs: London, UK, 1973.

2. Zelenika, I.; Pearce, J.M. Barriers to Appropriate Technology Growth in Sustainable Development. J. Sustain. Dev. 2011, 4, 12. [CrossRef]

3. Cash, D.W.; Clark, W.C.; Alcock, F.; Dickson, N.M.; Eckley, N.; Guston, D.H.; Jäger, J.; Mitchell, R.B. Knowledge systems for sustainable development. Proc. Natl. Acad. Sci. USA 2003, 100, 8086-8091. [CrossRef] [PubMed]

4. Sheila, J.; Markle, G.E.; Peterson, J.C.; Pinch, T. The Handbook of Science and Technology Studies; SAGE: Thousand Oaks, CA, USA, 1995.

5. Hackett, E.J.; Amsterdamska, O.; Lynch, M.; Wajcman, J. The Handbook of Science and Technology Studies, 3rd ed.; MIT Press: Cambridge, MA, USA, 2008.

6. Ulrike, F.; Fouche, R.; Miller, C.A.; Smith-Doerr, L. The Handbook of Science and Technology Studies, 4th ed.; MIT Press: Cambridge, MA, USA, 2017.

7. Bijker, W.E.; Hughes, T.P.; Pinch, T. The Social Construction of Technological Systems; MIT Press: Cambridge, MA, USA, 1987.

8. Jasanoff, S. States of Knowledge: The Co-Production of Science and Social Order; Routledge: London, UK, 2004.

9. Shapin, S. Never Pure; Johns Hopkins Press: Baltimore, MD, USA, 2010.

10. Clark, W.C.; van Kerkhoff, L.; Lebel, L.; Gallopin, G. Crafting Usable Knowledge for Susatinable Development. Proc. Natl. Acad. Sci. USA 2016, 113, 4570-4578. [CrossRef] [PubMed]

11. Dilling, L.; Lemos, M.C. Creating usable science: Opportunities and constraints for climate knowledge use and their implications for science policy. Glob. Environ. Chang. 2011, 21, 680-689. [CrossRef]

12. Reid, R.S.; Nkedianye, D.; Said, M.Y.; Kaelo, D.; Neselle, M.; Makui, O.; Onetu, L.; Kiruswa, S.; Kamuaro, N.O.; Kristjanson, P.; et al. Evolution of Models to Support Community and Policy Action with Science: Balancing Pastoral Livelihoods and Wildlife Conservation in Savannas of East Africa. 2009. Available online: https://doi.org/10.1073/pnas.0900313106 (accessed on 10 November 2020).

13. Sirianni, C.; Zuboff, S. In The Age of the Smart Machine: The Future of Work and Power. Contemp. Sociol. A J. Rev. 1989, 18, 713. [CrossRef]

14. Rheinberger, H.-J. Toward a History of Epistemic Things; Stanford University Press: Palo Alto, CA, USA, 1997.

15. Henke, C.R. Cultivating Science, Harvesting Power; MIT Press: Cambridge, MA, USA, 2008.

16. Matson, P.A. Seeds of Sustainability; Island Press: Washington, DC, USA, 2011.

17. Twain, M. A Connecticut Yankee in King Arthur's Court; Chatto and Windus: London, UK, 1889.

18. Clarke, A.C. Profiles of the Future; Harper and Row: New York, NY, USA, 1962.

19. Shelby, R.; Perez, Y.; Agogino, A.M. Partnering with the Pinoleville Pomo Nation: Co-Design Methodology Case Study for Creating Sustainable, Culturally Inspired Renewable Energy Systems and Infrastructure. Sustainability 2012, 4, 794-818. [CrossRef]

20. Parker, J.N.; Hackett, E.J. Hot Spots and Hot Moments in Scientific Collaborations and Social Movements. Am. Sociol. Rev. 2012, 77, 21-44. [CrossRef]

21. Star, S.L.; Griesemer, J.R. “Translations” and Boundary Objects: Amateurs and Professionals in Berkeley's Museum of Vertebrate Zoology. Soc. Stud. Sci. 1989, 19, 387-420. [CrossRef]

22. Gieryn, T.F. Cultural Boundaries of Science: Credibility on the Line; University of Chicago Press: Chicago, IL, USA, 1999.

23. Parker, J.N.; Crona, B. On being all things to all people: Boundary organizations and the contemporary research university. Soc. Stud. Sci. 2012, 42, 262-289. [CrossRef] 
24. Kirchhoff, C.J.; Esselman, R.; Brown, D.G. Boundary organizations to boundary chains: Prospects for advancing climate science application. Clim. Risk Manag. 2015, 9, 20-29. [CrossRef]

25. O'Mahony, S.; Bechky, B.A. Boundary Organizations: Enabling Collaboration among Unexpected Allies. Adm. Sci. Q. 2008, 53, 422-459. [CrossRef]

Publisher's Note: MDPI stays neutral with regard to jurisdictional claims in published maps and institutional affiliations.

(C) 2020 by the author. Licensee MDPI, Basel, Switzerland. This article is an open access article distributed under the terms and conditions of the Creative Commons Attribution (CC BY) license (http://creativecommons.org/licenses/by/4.0/). 